\title{
Level assessment of good practice in food industry of Ukraine
}

\section{Tamara Berezianko}

National University of Food Technologies, Kiyv, Ukraine

\begin{tabular}{|c|c|}
\hline & Abstract \\
\hline \multicolumn{2}{|l|}{ Keywords: } \\
\hline & Introduction. The business practices of corporate food \\
\hline Corporate & industry enterprises of Ukraine are examined in order to \\
\hline Sector & assess accordance to the requirements of EU corporate \\
\hline Responsibility & social responsibility. \\
\hline Surveys & Materials and methods. The subject of study is \\
\hline & business practices oligopolistic companies oil and fat \\
\hline & industry of Ukraine. For the purpose of the study was the \\
\hline Oligopoly & approach, built on the method of individual interviews and \\
\hline Article history: & $\begin{array}{l}\text { industry, the association of experts, scientists and leading } \\
\text { experts of the industry. Total surveyed } 33 \text { companies } \\
\text { participated, of which } 9 \text { or } 25 \% \text { belong to the oil and fat }\end{array}$ \\
\hline Received 16.09.2016 & industry. \\
\hline $\begin{array}{l}\text { Received in revised } \\
\text { form } 27.06 .2017\end{array}$ & $\begin{array}{l}\text { Results. The lawmakers admit the differences between } \\
\text { the practice and standards at all stages of market economy. }\end{array}$ \\
\hline Accepted 05.09.2017 & A lot of scientists consider oligopolistic market to be very \\
\hline $\begin{array}{l}\text { Corresponding } \\
\text { author: }\end{array}$ & $\begin{array}{l}\text { declared corporate practices of leading companies in the } \\
\text { sphere of oil-fat production, we have noticed a tendency to }\end{array}$ \\
\hline Tamara Berezianko & ignore the guidelines of the European community while \\
\hline E-mail: & conscious and voluntary stick to corporate responsible \\
\hline t_berezianko@mail.ru & $\begin{array}{l}\text { behavior. The process of negative business practices is } \\
\text { characterized by fluctuations: corruption and manipulation. }\end{array}$ \\
\hline & $\begin{array}{l}\text { It is noteworthy that observance of internal and international } \\
\text { legislative directions is of more formal character. }\end{array}$ \\
\hline $\begin{array}{l}\text { DOI: } 10.24263 / 2310- \\
\text { 1008-2017-5-1-16 }\end{array}$ & $\begin{array}{l}\text { Conclusion. The level of owner and management } \\
\text { behavior in corporate environment may be defined as } \\
\text { opportunistic and almost manipulative. That's why it is } \\
\text { necessary to find reasonable balance between the } \\
\text { requirements of business decisions, control over their } \\
\text { orientation and social counterbalance and legal norms of } \\
\text { EU. }\end{array}$ \\
\hline
\end{tabular}




\section{Introduction}

The market developed world has got two systems of influence on the components of internal and external society: financial and sociological market regulator with the USA and Europe as its samples correspondingly. The impact of oligopolistic form of the market was traditionally considered by the scientists from the point of view of ensuring the equal possibilities to compete. E. Chemberlin [1] and J. Robinson [2] have studied the fundamentals of the theories of imperfect competition. Modern researches consider the possibility of blocking the mechanisms of self-regulation of the market to be the main disadvantage of oligopolistic market [3]. The new approaches to the role of the social responsibility of business were analyzed in the researches of M. Porter and P. Druker [4] . Degree, aspects and areas of responsibility of business are often discussed in scientific publications.

The scientists consider the methods of corporate social responsibility to be the means of improvement of competitiveness of national economy [5] . The scientists pay attention in their researches to the necessity of development of relations between business partners. The social responsibility is studied at the level of enterprise and public policy, though there are the differences in interpretation. In recent years the most significant researches belong to Y.M. Pakhomov [6], M. Zveryakov [7], Kh.R. Gal'chak [8], I. Burakovskiy [9].

A concept "respectable business practice" was almost not investigated in national economic literature (the concept "ethics" is often substituted by the concept "etiquette") [10]. This term is used in jurisprudence as analogue of restrictive business practice in the course of competition regulation and development of antitrust laws [11,12]. Meanwhile the current economic situation, national market development and lack of correspondence between business practice and requirements of developed markets induce business environment to formalize this area. Yes, The National Bank of Ukraine has prepared the project of The Behavior Code and business practice for participants of the interbank foreign exchange market of Ukraine [13].

Ukraine aims at European integration. That's why it is necessary to study the impact evaluation and social direction of corporate sector in the context of compliance of national practices with the requirements of the EU to the activity of corporate sector. A lot of EUcountries consider corporate social responsibility to be a part of main policies and principles of state administration, for example in Denmark, Finland, Sweden and France, and some countries rely on bona fide activity of the companies, for example in Slovenia, Greece, Ireland and the Netherlands.

\section{Materials and methods}

The subject of research is business practices oligopolistic companies oil and fat industry of Ukraine.

For the purpose of the study was the approach, built on the method of individual interviews and questionnaires trainees postgraduate education of the industry, the association of experts, scientists and leading experts of the industry [9].

Total surveyed 33 companies participated, of which 9 or $25 \%$ belong to the oil and fat industry. 


\section{Result and discussion}

A lot of scientists consider oligopolistic market to be very closed and difficult for getting reliable information by the system. That's why quantitative and qualitative approaches were used for applied stage of analysis. The implementation of the conception of social responsibility requires the introduction into everyday activity of the company a wide range of the aspects of responsible management organization, observance of human rights during the activity of the company, improvement of socially responsible labor relations, management of fair operational activity, protection of environment, observance and development of the system of consumer rights protection, support of local communities development and cooperation with them.

To this purpose it was used the method of direct measuring with the use of IFC methodology into the corrected example [14].

Total public effect of responsible activity (thousand, UAH)

Table 1

\begin{tabular}{|c|c|c|c|c|}
\hline $\begin{array}{c}\text { Oligopolistic } \\
\text { core }\end{array}$ & Social effect & $\begin{array}{c}\text { Corporate } \\
\text { effect }\end{array}$ & Public effect & Total \\
\hline Enterprise "K" & 67696,0 & 1011532,0 & 437525,9 & 437525,9 \\
\hline Enterprise "D" & 23678,2 & 731562,0 & 49289,3 & 804529,5 \\
\hline Enterprise "V" & 29462,1 & 607605,0 & 200534,0 & 837601,1 \\
\hline Total & 120836,3 & 8934799,0 & 687349,2 & 3158884,5 \\
\hline
\end{tabular}

Quantitative approach was based on the identification of market condition, its corporate structure, applied strategies, basic economic and productive descriptions of its participants taking into account the behavior features of oligopolistic core.

Table 2

Estimation of the effect from the responsible activity of oligopolistic core, \%

\begin{tabular}{|c|c|c|c|c|}
\hline $\begin{array}{c}\text { Oligopolistic } \\
\text { core }\end{array}$ & Social effect & $\begin{array}{c}\text { Corporate } \\
\text { effect }\end{array}$ & Public effect & Total \\
\hline Enterprise "K" & 4,5 & 66,7 & 28,8 & 48,0 \\
\hline Enterprise "D" & 2,9 & 90,9 & 6,1 & 25,5 \\
\hline Enterprise "V" & 3,5 & 72,5 & 23,9 & 26,5 \\
\hline Total & 3,8 & 74,4 & 21,8 & 100 \\
\hline
\end{tabular}

The use of quantitative estimations does not allow understanding the level of impact and responsibility concerning company assets and its load on the use of society resources: the top priority task of OECD and European commission consists in harmonization of surveys in non-European countries. Some another approach was applied for the purposes of this research: the method of individual interviews and questionnaires of visitors of postgraduate courses for employees, experts of corresponding association, scientists and leading specialists of this industry. 
Relative comparison proves that the effect of the activity is mainly concentrated in corporate sector, and the social effect is quite insignificant.

Table 3

Internal policies and business practices of oil-fat companies

\begin{tabular}{|c|c|c|}
\hline Companies & Area of business practices & $\begin{array}{c}\text { Compliance } \\
\text { with the EU } \\
\text { principles, } \\
\text { points }\end{array}$ \\
\hline \multirow{5}{*}{$\begin{array}{l}\text { Enterprise } \\
\text { "K" }\end{array}$} & Tendency to implement and support fair business practice & \multirow[t]{5}{*}{12} \\
\hline & $\begin{array}{l}\text { To introduce positive practices into the activity of new } \\
\text { companies. To bring general and short-term strategies up } \\
\text { to the standard of farm enterprises and procurement } \\
\text { departments. There is a special training "smart farm" for } \\
\text { this purpose. It helps to prepare raw materials } \\
\text { independently. }\end{array}$ & \\
\hline & $\begin{array}{l}\text { To publish information about insider agreements, assigned } \\
\text { auditor, incentive system, list of shareholders with more } \\
\text { than } 5 \% \text { of total amount of votes, dividend charge and } \\
\text { changes of share prices, periodicity of meetings, trade } \\
\text { rules. }\end{array}$ & \\
\hline & $\begin{array}{l}\text { To publish financial report, GRI-requirements are not } \\
\text { implemented. }\end{array}$ & \\
\hline & $\begin{array}{l}\text { There is no information about joint enterprises on the web- } \\
\text { sites. }\end{array}$ & \\
\hline \multirow[t]{4}{*}{$\begin{array}{l}\text { Enterprise } \\
\text { "D" }\end{array}$} & $\begin{array}{l}\text { The code of conduct includes ethics and responsibility: } \\
\text { reputation based on observance of legality, fair and ethic } \\
\text { competition, anticorruption behavior, true accounting, } \\
\text { fulfillment of obligations, prevention of conflict of } \\
\text { interests, financial information is distinguished by the } \\
\text { kinds of activity (including the credit rating for the last } 5 \\
\text { years), information about business practices is } \\
\text { characterized by trade and industrial features. }\end{array}$ & 10 \\
\hline & $\begin{array}{l}\text { Cooperation: scientific assistance to the partners and } \\
\text { professional assessment, cooperation with the partners, } \\
\text { that adhere to the CRS-requirements. }\end{array}$ & \\
\hline & The report is not presented. & \\
\hline & The policy of the company enterprises is not itemized. & \\
\hline \multirow[t]{2}{*}{$\begin{array}{l}\text { Enterprise } \\
\text { "V" }\end{array}$} & $\begin{array}{l}\text { There is no business policy of the company on the web- } \\
\text { site, but there is a financial report. The policy of the } \\
\text { company enterprises is not itemized and it is not structured } \\
\text { in accordance with the types of company activity. }\end{array}$ & \multirow[t]{2}{*}{8} \\
\hline & $\begin{array}{l}\text { There is } 1 \text { web-site of the company for advertising } \\
\text { purposes. }\end{array}$ & \\
\hline
\end{tabular}

The first empirical research of business responsibility degree was carried out in 2002 by the Charity fund "Intellectual prospects" on the request of UNICEF in Ukraine. The next survey was conducted by the Consortium for Enhancement of Ukrainian Management 
Education and by the Center of Innovations and Development in 2004. In 2006 the corporate social responsibility (CSR) was studied by the Carpathian foundation for the study of stimuli and obstacles during the introduction of the social responsibility of business (SRB). In 2010 OECD and UNO assisted in assessment of the social responsibility of business in order to create a platform for the dialogue between business and government. In 2013 The Institute of Industrial Economics of NAS of Ukraine has revealed the results of the expert survey among the scientific specialists and teachers of Ukraine on the problems of social responsibility of individuals, society, business and state. The Center for the development of CSR in Kyiv plays a significant role in spreading of CSR. And, finally, in 2014 the National University of Food Technologies started the cycle of researches for the estimation of the state, typical problems and monitoring of corporate social and public responsibility degree in food industry.

Having analyzed the existing and declared corporate practices of leading companies in the sphere of oil-fat production, we have noticed a tendency to ignore the guidelines of the European community while conscious and voluntary stick to corporate responsible behavior. The fulfillment of this requirement mostly remains stagnated and is more cosmetic tool that makes internal processes better.

Table 4

Assessment of negative business practices (corruption) in the sphere of oil-fat production, $\%$

\begin{tabular}{|c|c|c|c|c|}
\hline \multirow[t]{2}{*}{ Index } & \multicolumn{2}{|c|}{$\begin{array}{l}\text { Bribe or corruption is } \\
\text { necessary }\end{array}$} & \multicolumn{2}{|c|}{$\begin{array}{c}\text { Hope on judicial or state } \\
\text { protection }\end{array}$} \\
\hline & 2013 & 2014 & 2013 & 2014 \\
\hline \multicolumn{5}{|l|}{ Company self-rating } \\
\hline $\begin{array}{l}\text { Companies within } \\
\text { oligopolistic core }\end{array}$ & 63 & 75 & 37 & 29 \\
\hline $\begin{array}{l}\text { Large-scale } \\
\text { enterprises }\end{array}$ & 56 & 65 & 33 & 20 \\
\hline $\begin{array}{l}\text { Medium-sized } \\
\text { enterprises }\end{array}$ & 60 & 60 & 23 & 15 \\
\hline Small enterprises & 59 & 58 & 10 & 15 \\
\hline \multicolumn{5}{|l|}{ Expert review } \\
\hline Corporate sector & 70 & 80 & 18 & 10 \\
\hline
\end{tabular}

*Composed by the author. Based on the results of expert reviews and interview answers

The process of negative business practices is characterized by fluctuations: corruption and manipulation. This is because of the first years of market economy in the country, when the first business processes were defined by speculative and corrigible relations of internal and external character. They were promoted during tax optimization by the leading international advisory organizations.

Pooling of state and business interests may lead to propagation of anticompetitive practices and its application by powerful market participants. The period of fast establishment of effective owner and the period, when business wanted to become a part of international business market may be associated with the start of pooling of state and business interests. 
Anticompetitive practices

(power pressure, raiding, management reserves, lobbying), \%

\begin{tabular}{|c|c|c|c|c|}
\hline Index & $\mathbf{2 0 0 6 - 2 0 0 9}$ & $\mathbf{2 0 1 0 - 2 0 1 2}$ & $\mathbf{2 0 1 3}$ & $\mathbf{2 0 1 4}$ \\
\hline $\begin{array}{c}\text { Companies within oligopolistic } \\
\text { core }\end{array}$ & 80 & 60 & 40 & 90 \\
\hline Large-scale enterprises & 29 & 25 & 18 & 27 \\
\hline Medium-sized enterprises & 10 & - & - & 12 \\
\hline Small enterprises & - & - & - & - \\
\hline Expert review & 27 & 19 & 19 & 32 \\
\hline
\end{tabular}

*Composed by the author. Based on the results of expert reviews and interview answers

Importance of informal relations between business and state, \%

Table 6

\begin{tabular}{|l|c|c|}
\hline \multicolumn{1}{|c|}{ Index } & $\mathbf{2 0 0 7 - 2 0 0 9}$ & $\mathbf{2 0 1 0 - 0 1 . 0 1 . 2 0 1 4}$ \\
\hline Tax administration & 51,7 & 30,7 \\
\hline Municipal authority & 50,0 & 26,1 \\
\hline $\begin{array}{l}\text { State authority } \\
\text { (ministries, Verkhovna Rada of Ukraine) }\end{array}$ & 49,3 & 24,0 \\
\hline Ministry of Internal Affairs & 46,5 & 26,6 \\
\hline Local authorities & 43,9 & 26,4 \\
\hline Total & 57,0 & 31,7 \\
\hline
\end{tabular}

*Composed by the author. Based on the results of individual interviews with boards of governors, management and experts

Table 7

Distribution of business expectations in accordance with the changes of business environment, \%

\begin{tabular}{|l|c|}
\hline \multicolumn{1}{|c|}{ Main business expectations } & Percentage \\
\hline Cease-fire & 76 \\
\hline $\begin{array}{l}\text { Productive lawmaking work of the Parliament in order to } \\
\text { normalize business environment }\end{array}$ & 41 \\
\hline Anti-corruption campaign & 40 \\
\hline State run public authorities must make transparent decisions & 26,3 \\
\hline Tax pressure minimization & 24,4 \\
\hline Public purchases without protectionism & 23,7 \\
\hline Improvement of public economic policy and administration & 21,8 \\
\hline Judicial reform & 20,0 \\
\hline $\begin{array}{l}\text { Economic development as a priority for state development } \\
\text { programs }\end{array}$ & 17,0 \\
\hline Clear economic policy & 9,6 \\
\hline Negative expectations & 9,3 \\
\hline
\end{tabular}

*Composed by the author. Based on the results of surveys and data [15] 
The data of above mentioned table partly proves the previous opinion. That's why it is possible to say, that there are particular factors that help to maintain internal competitiveness of oligopolistic core within the sphere of oil-fat production. These factors are: to possess advantages in costs, to use extensively administrative resources, to use rent model for own benefit, to pool the interests of oligopolists and authorities. Further, it is shown that the main business expectations don't belong to the economic sphere.

It is noteworthy that observance of internal and international legislative directions is of more formal character. That's why it is possible to detect not only gap in law but also break in law. That's why the requirements of European society to introduce the reforms into this sphere are reasonable.

Observance of national and international laws of corporate sector

Table 8 within the sphere of oil-fat production

\begin{tabular}{|l|l|c|}
\hline \multicolumn{1}{|c|}{ Companies } & \multicolumn{1}{|c|}{ Characteristic of social practices } & $\begin{array}{c}\text { Compliance with } \\
\text { the EU principles, } \\
\text { \% }\end{array}$ \\
\hline Enterprise "K" & $\begin{array}{l}\text { The observance of all legal regulations, } \\
\text { international standards, national laws and } \\
\text { internal directives is announced }\end{array}$ & 60 \\
\cline { 2 - 2 } & $\begin{array}{l}\text { Observance of international labor legislation } \\
\text { Jobs and production processes completely } \\
\text { comply with the health protection and labor } \\
\text { safety standards and requirements }\end{array}$ & \\
\hline Enterprise "D" & $\begin{array}{l}\text { Law-abiding business process, observance of } \\
\text { the safety standards at foodstuff production and } \\
\text { environmental protection }\end{array}$ & \\
\cline { 2 - 3 } & $\begin{array}{l}\text { Observance of international labor safety } \\
\text { standards }\end{array}$ & \\
\hline & No information & \\
\hline
\end{tabular}

* Composed by the author. Based on the results of reviews

The interview results confirm the existence of great differences: companies under complete foreign control possess too formalized management. Certainly this fact reduces the risks but deteriorates efficiency and situational decision making. However management of Ukrainian companies faces the unformalized absence to permit decision making. Additional disputes between employers and among workers are caused by uncertain regulations.

Not only the conflict between shareholders (owners) and management and the conflict between the minority and majority of shareholders is not typical for the national corporate sector, but it is typical in the corporate practice in the USA and Europe correspondingly, but also conflict between institutional components: between all the interests of the society and consolidated interests of the corporate sector and state administration. 
Table 9

Expert rating of management opportunism in the sphere of oil-fat production

\begin{tabular}{|l|c|c|c|c|}
\hline \multicolumn{1}{|c|}{ Companies } & Oligopolistic & $\begin{array}{c}\text { Large- } \\
\text { scale }\end{array}$ & $\begin{array}{c}\text { Medium- } \\
\text { sized }\end{array}$ & Small \\
\hline Closed sale of shares & - & partly & mainly & - \\
\hline $\begin{array}{l}\text { Legal procedure due to breach of } \\
\text { the contract }\end{array}$ & partly & partly & partly & - \\
\hline Malpractice regarding clients & partly & partly & mainly & partly \\
\hline Breach of the strategy & partly & partly & mainly & - \\
\hline $\begin{array}{l}\text { Conflict situations among the } \\
\text { employees }\end{array}$ & partly & mainly & mainly & - \\
\hline Non-transparent management & partly & yes & yes & yes \\
\hline
\end{tabular}

* Composed by the author. Based on the results of personal interviews with management and experts

The index of revealed information about business agreements was suggested by the owner and manager in order to rate their manipulative and opportunistic behavior.

The above mentioned index consists of five components. These components were modified and adapted to the national business terms by the author. As a result the rating scale was suggested in order to rate manipulative and opportunistic behavior of the owner and/or manager of corporate enterprise of food industry.

Table 10

Manipulative and opportunistic behavior of the owner of oligopolistic core within the sphere of oil-fat production, (points)

\begin{tabular}{|l|c|c|c|}
\hline \multicolumn{1}{|c|}{ Index } & \multicolumn{2}{|c|}{ Oligopolistic core } \\
\cline { 2 - 4 } & $\begin{array}{c}\text { Enterprise } \\
\text { "K" }\end{array}$ & $\begin{array}{c}\text { Enterprise } \\
\text { "D" }\end{array}$ & $\begin{array}{c}\text { Enterprise } \\
\text { "V" }\end{array}$ \\
\hline $\begin{array}{l}\text { The presence of corporate body, that licenses the } \\
\text { agreements of property assets sale, withdrawal of } \\
\text { the assets from circulation, restructuring and } \\
\text { merging }\end{array}$ & 2 & 2 & 1 \\
\hline $\begin{array}{l}\text { The necessity to reveal information to the society } \\
\text { about agreements concluded by shareholders, } \\
\text { regulating authority }\end{array}$ & 1 & 1 & 1 \\
\hline $\begin{array}{l}\text { The presence of request to publish information } \\
\text { about agreements }\end{array}$ & 1 & 1 & 1 \\
\hline $\begin{array}{l}\text { The presence of request to inform the board of } \\
\text { governors or supervisory board about conflict of } \\
\text { interests }\end{array}$ & 0 & 0 & 1 \\
\hline $\begin{array}{l}\text { The necessity to involve external auditor in order to } \\
\text { pre-inspect the agreement }\end{array}$ & 0 & 0 & 0 \\
\hline Total & 4 & 4 & 4 \\
\hline Compliance with the standards (10), \% & 40 & 40 & 40 \\
\hline
\end{tabular}

*Composed by the author. Based on the results of interviews and expert reviews 


\section{- Economics and Management}

The level of owner and management behavior in corporate environment may be defined as opportunistic and almost manipulative. That's why it is necessary to find reasonable balance between the requirements of business decisions, control over their orientation and social counterbalance and legal norms. For solving this problem it is necessary to determine the limits and forms of the responsibility of the participants of regulation process. The system of Codes is the means of implementation of this direction in Europe and in the world.

\section{Conclusions}

The lawmakers admit the differences between the practice and standards at all stages of market economy. The system of clannish interests still does not allow to introduce real reforms. The lack of correspondence between economic policy, directions of regulatory influences and real requirements of national business environment and requirements of developed continental markets endangers European integration way of the nation.

\section{References}

1. Chamberlin Ed. (1933), The Theory of Monopolistic Competition, Harvard University Press, Cambridge, p. 74

2. Robinson J. (1933), The Economics of Imperfect Competition, London, p. 27

3. Ietto-Gillies Gr. (2005), Transnational Corporations and International Production, Edward Elgar, Lviv, p. 88.

4. Porter M.E. (2006), Strategy of Society:The Link Between Competitive Advantage and Corporative social Responsibility, Harvard Business Review, pp. 78-92

5. Krivoruchko J.N., Prima L.R. (2010), Formuvannya konkurentnih perevag pidpriemstva u konteksti upravlinnya vidnosinami iz biznes-partnerami, Visnik Natsionalnogo universitetu Lvivska politehnika, 690, pp. 347-352

6. Pakhomov U., Pakhomov S. (2009), Ekonomicheskiy krizis: ukrainskiy variant, Obschestvo i ekonomika, pp. 3, 64

7. Zveryakov M. (2010), Liberalnaya ideya I modernizatsiya economiki Ukrainy, Economika Ukrainy, 7, pp.7-12.

8. Galtchak H.R. (2012), Printsip sotsialnoyi vidpovidalnosti u konteksti sotsialno orientovanogo menedgmentu, Visnik Natsionalnogo universitetu Lvivska politehnika, 725, pp. 265-269.

9. Burakovsky I.(2014), Ugoda pro asotsiatsiyu midg Ukrainoyu ta EC: perevagi ta vikliki dlya biznesu, Available at: www.ier.com.ua

10. Vereh S.M. Etika povedinki derdgavnih sludgbovtsev, Available at: http://kds.org.ua/blog/etika-povedinki-derzhavnih-sluzhbovtsiv-stan-problemi-ishlyahi-ih-virishennya

11. Evtushenko G.I., Kantsur I.G. Korporativna kultura ta dilovi etiket, Available at: http://www.google.com.ua/url?sa $=\mathrm{t} \& \mathrm{rct}=\mathrm{j} \& \mathrm{q}=\& \mathrm{esrc}=\mathrm{s} \&$ source $=$ web\&cd $=9 \& \mathrm{ved}=0 \mathrm{C}$ FIQFjAI\&url=http\%3A\%2F\%2Fasta.nudpsu.com.ua\%2Fimages\%2Fstories\%2FNEW S\%2F 1812 13\%2F\%25D0\%259D\%25D0\%259C\%25D0\%259A\%2520\%25D0\%25 BA\%25D0\%25BE\%25D1\%2580\%25D0\%25BF\%25D0\%25BE\%25D1\%2580\%25D0 $\% 25 \mathrm{~B} 0 \% 25 \mathrm{D} 1 \% 2582 \% 25 \mathrm{D} 0 \% 25 \mathrm{~B} 8 \% 25 \mathrm{D} 0 \% 25 \mathrm{~B} 2 \% 25 \mathrm{D} 0 \% 25 \mathrm{BD} \% 25 \mathrm{D} 0 \% 25 \mathrm{~B} 0 \% 2$ $520 \% 25 \mathrm{D} 0 \% 25 \mathrm{BA} \% 25 \mathrm{D} 1 \% 2583 \% 25 \mathrm{D} 0 \% 25 \mathrm{BB} \% 25 \mathrm{D} 1 \% 258 \mathrm{C} \% 25 \mathrm{D} 1 \% 2582 \% 255 \mathrm{~B}$ 


\section{- Economics and Management -}

1\%255D.doc\&ei=smWvVN6ZDMWqywP8xYL4Dw\&usg=AFQjCNErUJTmAChd2v kRNH5O385nMEMr0g

12. Yurydychnyi sloovnyk, Available at:

http://kodeksy.com.ua/dictionary/o/obmezhuval_na_dilova_praktika.htm

13. Obgovorennya proektu Kodeksu povedinky tà dilovoii praktyki utchastnikiv migbankivskogo valiutnogo rynku, National Bank of Ukraine, Available at: http://www.bank.gov.ua/control/uk/publish/article?art_id=11958586

14. IFC, Available at:

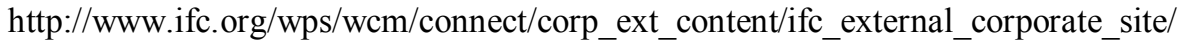
home

15. Ukraine-analyisen (2014), Available at: www.laender-analysen.de/ukraine 